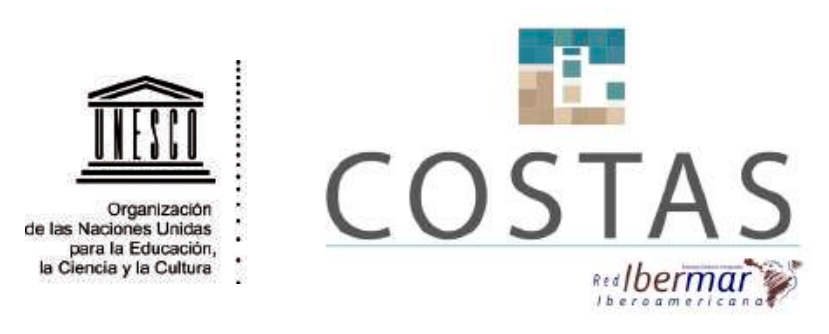

Miura, A. Noernberg, M. 2020. Mapping of Conflicts of Use and Occupation of the Paranaguá Estuary Complex and Shallow Platform: Subsidies for Marine Spatial Planning. Revista Costas, 2(2): 53-72. doi: $10.26359 /$ costas. 0902

Scientific Article / Artigo Científico / Artículo Científico

Mapeamento de Conflitos de Uso e Ocupação no Complexo Estuarino de Paranaguá e Plataforma Rasa: Subsídios para o Planejamento Espacial Marinho

\title{
Mapping of Conflicts of Use and Occupation of the Paranaguá Estuary Complex and Shallow Platform: Subsidies for Marine Spatial Planning
}

Universidade Federal do Paraná, Pontal do Paraná, PR, Brasil.

Submitted: August 2020

Accepted: November 2020

Associate Editor: xEduardo Martins

\author{
Aika Miura, Mauricio A. Noernberg \\ *e-mail: aikasmiura@gmail.com
}

Keywords: Coastal management, geoprocessing, protected coastal areas, conservation units, coastal zone.

\begin{abstract}
The preference for housing in coastal environments has become a human strategy due to several factors; as biodiversity wealth, geographic strategy, or abundance of fishing resources. The coastal and estuarine environment is a place of multiple uses for industrial, commercial, housing, port, and ecologically essential purposes. An effective Marine Spatial Planning (MSP) is essential to establish a rational organization of the use of the marine space and the interactions between its uses, in order to balance the demands of development with the need to protect marine ecosystems, as well as to achieve social and economic objectives in a transparent and planned way (UNESCO-IOC, 2011). The present study identifies, maps, and separates the main human activities developed in the territorial space of the Paranaguá Estuarine Complex - Paraná,
\end{abstract}




\section{COSTAS}

Revista Costas, Vol. 2 (2), 2020

Brazil (CEP) and nearby shallow platform. Through Geographic Information Systems (GIS) and remote sensing techniques, it established the conflict zones and their impact on the marine environment and quantified areas of environmental protection affected by human activities. The results shows the regions between Pontal do Sul and Ponta do Poço, the southern portion of Baía das Laranjeiras and the Rasa Platform classified with High Conflict levels. Approximately $19 \%$ of the administrative limits of the Conservation Units (CU) in the region and 33\% of the Damping Zones (DZ) are affected by anthropic activities and uses. In this way, the spatialization of existing conflicts in a place with broad uses for different purposes, would support to define economic strategies; direct actions for public policies, and decision making. Still, it can be a tool for the mitigation and compensation of environmental and social impacts, due to human activities in the study area.

\section{Resumo}

A preferência pela habitação de ambientes litorâneos se tornou uma estratégia dos humanos devido a diversos fatores; como riqueza de biodiversidade; estratégia geográfica ou abundância de recursos pesqueiros. $\mathrm{O}$ ambiente costeiro e estuarino tem grande importância ecológica e, ao mesmo tempo, é local de múltiplos usos para fins industriais, comerciais, habitacionais e portuários. Um Planejamento Espacial Marinho (PEM) eficaz é fundamental para estabelecer uma organização racional da utilização do espaço marinho e das interaçóes entre seus usos, a fim de equilibrar as demandas de desenvolvimento com a necessidade de proteger os ecossistemas marinhos, bem como de alcançar objetivos sociais e econômicos de forma transparente e planejada (UNESCO-IOC, 2011). Este trabalho identifica, mapeia e separa as principais atividades antrópicas desenvolvidas no espaço territorial do Complexo Estuarino de Paranaguá - Paraná, Brasil e na plataforma rasa adjacente. Através de técnicas de Sistemas de Informação Geográfica (SIG) e sensoriamento remoto, estabelece as principais zonas de conflitos bem como seu grau de impacto no ambiente marinho e quantifica áreas de proteção ambiental atingidas por atividades antrópicas. Os resultados apresentam as regiốes entre Pontal do Sul e Ponta do Poço; a porçáo sul da Baía das Laranjeiras e a Plataforma Rasa classificadas com níveis de Alto Conflito. Cerca de 19\% das Unidades de Conservação (UC) da região e 33\% das Zonas de Amortecimento (ZA) são afetadas por atividades e usos antrópicos. Desta forma, a espacializaçáo dos conflitos existentes de diferentes finalidades pode dar suporte para definir estratégias econômicas; dirigir açóes para políticas públicas e tomadas de decisóes. Ainda, pode ser sinalizador para a mitigação e compensação de impactos ambientais e sociais, devido às atividades antrópicas na área de estudo. Palavras-chave: Gerenciamento Costeiro, Área marinhas protegidas, Geoprocessamento, Unidades de Conservação. Zona Costeira.

\section{Introdução}

A maioria das áreas costeiras do mundo são áreas de uso múltiplo, onde diferentes atividades humanas ocorrem. As áreas costeiras atraem uma variedade de usos concorrentes que às vezes se sobrepóem, causando efeitos adversos uns sobre os outros (conflitos usuário-usuário) (Cicin-Sain \& Knecht, 1998 apud Tuda, 2014). Neste mesmo contexto, o aumento da demanda de uso das águas estuarinas e costeiras do Paraná é reflexo dos inúmeros atributos de sua costa e dos crescentes interesses sociais que buscam recursos valoráveis ou lazer (Castella, 2006).
O Projeto Gestáo Integrada da Zona Costeira do Paraná com Ênfase na Área Marinha dentro do Programa Nacional de Meio Ambiente - PNAMA II classificou os usos e a conservação nos ambientes costeiros paranaenses baseado em informaçóes ambientais, identificação de conflitos e processos socioambientais (MMA, 2004). Entretanto, os principais conflitos entre usos no Litoral do Paraná ainda são desconhecidos. Assim, o mesmo documento conclui que a intensificação do uso dos ambientes estuarinos e costeiros, associada a critérios normativos de difícil 
entendimento, geram conflitos de usos dos recursos marinhos e dos espaços aquáticos em razão das atividades que convivem nem sempre de forma harmoniosa.

Com o uso crescente e competitivo dos usos e recursos, alguns compromissos foram firmados para proteger o meio ambiente através de, por exemplo, a designação de áreas marinhas protegidas. $\mathrm{O}$ uso de técnicas de SIG e sensoriamento remoto em conjunto com pesquisas em ciências sociais e naturais aprofunda a compreensão de questôes antropológicas (Aswani \& Lauer, 2006), tais como padróes de comportamentos, locais de vulnerabilidade social, conflitos territoriais, etc.

Os territórios não são apenas espaços físicos, são também espaços sociais e culturais onde se manifestam as relaçōes e as ideias (Fernandes, 2008b). Para a compreensão dessas manifestações e relações entre os usos e as pessoas, Sistemas de Informaçóes Geográficas (SIG) são utilizados, pois são capazes de representar multiplicidade de usos e visôes. Também proporcionam uma perspectiva interdisciplinar de utilização do espaço geográfico, ajudando os usuários a tomarem decisóes fundamentadas em informação espacial originada da investigação dos padróes existentes, bem como suas relaçóes.

Desta forma, a espacialização dos conflitos existentes pode ser utilizada para definir estratégias econômicas; dirigir açóes para políticas públicas e tomadas de decisóes; quantificar impactos em áreas de importância ecológica e áreas ocupadas por populaçóes tradicionais e fornecer informaçóes importantes para consolidar o Planejamento Espacial Marinho (PEM) do local. O PEM é uma forma prática de criar e estabelecer uma organização mais racional da utilização do espaço marinho e das interaçóes entre seus usos, a fim de equilibrar as demandas de desenvolvimento com a necessidade de proteger os ecossistemas marinhos, bem como de alcançar objetivos sociais e econômicos de forma transparente e planejada (UNESCO-IOC, 2009).

Elaborado pela Unesco-IOC, o guia de planejamento espacial marinho estabelece 10 etapas chave para uma gestão ecossistêmica de zonas marinhas. Dentre elas, este trabalho enquadra nas etapas 5 e 6: "Analisar as condiçóes existentes" e "Analisar as condiçōes futuras", respectivamente. Desta forma, as metodologias apresentadas poderiam ser utilizadas para realizar um mapa de zonas sensíveis desde um ponto de vista ecológico e biológico; mapas de atividades e pressóes humanas existentes na área de estudo e como principal enfoque na avaliação de possíveis conflitos e compatibilidades entre os usos existentes e o meio ambiente.

Se os recursos marinhos devem ser usados de forma sustentável, é preciso encontrar maneiras de conciliar as diferentes demandas econômicas, sociais e ambientais que são colocadas no ambiente marinho (Gilliland, 2008). Neste contexto, é necessário oferecer informaçóes adequadas para subsidiar as tomadas de decisóes, planos de conservação e o gerenciamento costeiro. O presente trabalho identifica e quantifica os conflitos de uso e ocupação da porção aquática no Complexo Estuarino de Paranaguá e na plataforma rasa adjacente visando compreender e qualificar o espaço marinho do litoral paranaense. 


\section{Material e métodos}

\section{Área de estudo}

A área de estudo, o Complexo Estuarino de Paranaguá (CEP), localizado na costa do estado do Paraná, região sul do Brasil (entre $25^{\circ} 16^{\prime}$ a $25^{\circ} 34^{\prime}$ S e $48^{\circ} 17^{\prime}$ a $48^{\circ} 42^{\prime} \mathrm{W}$ ) (figura 1) faz parte de um grande sistema estuarino subtropical. Possui área da bacia hidrográfica de $3870 \mathrm{~km}^{2}$, corpo hídrico de $551,8 \mathrm{~km}^{2}$ e 295,5 $\mathrm{km}^{2}$ de áreas inundadas como baixios e manguezais (Noernberg, 2006). Composto por duas principais baías: Paranaguá e Antonina $\left(260 \mathrm{~km}^{2}\right)$ e a de Laranjeiras e Pinheiros $\left(200 \mathrm{~km}^{2}\right)$, o estuário está conectado com o oceano Atlântico por três canais principais - da Galheta, do Norte e o de Superagüi (Lana et al., 2001).
A região passou por alguns ciclos econômicos e produtivos com a chegada gradual dos imigrantes no local. Entende-se que as primeiras manifestaçóes de atividades econômicas foi a extração de madeira, depois palmito, banana e por fim a agropecuária. A pesca, que em tempos passados era uma atividade complementar à agricultura, a partir de meados do século $\mathrm{XX}$, passou a ser a fonte de renda mais importante para as comunidades caiçaras (Enciclopédia Caiçara, 2005). Atualmente, destaca-se no litoral paranaense atividades de lazer e turismo; pesca artesanal, recreativa e industrial; atividades portuárias relacionadas ao Porto de Paranaguá; empreendimentos associados a atividade portuária e concomitante às unidades de

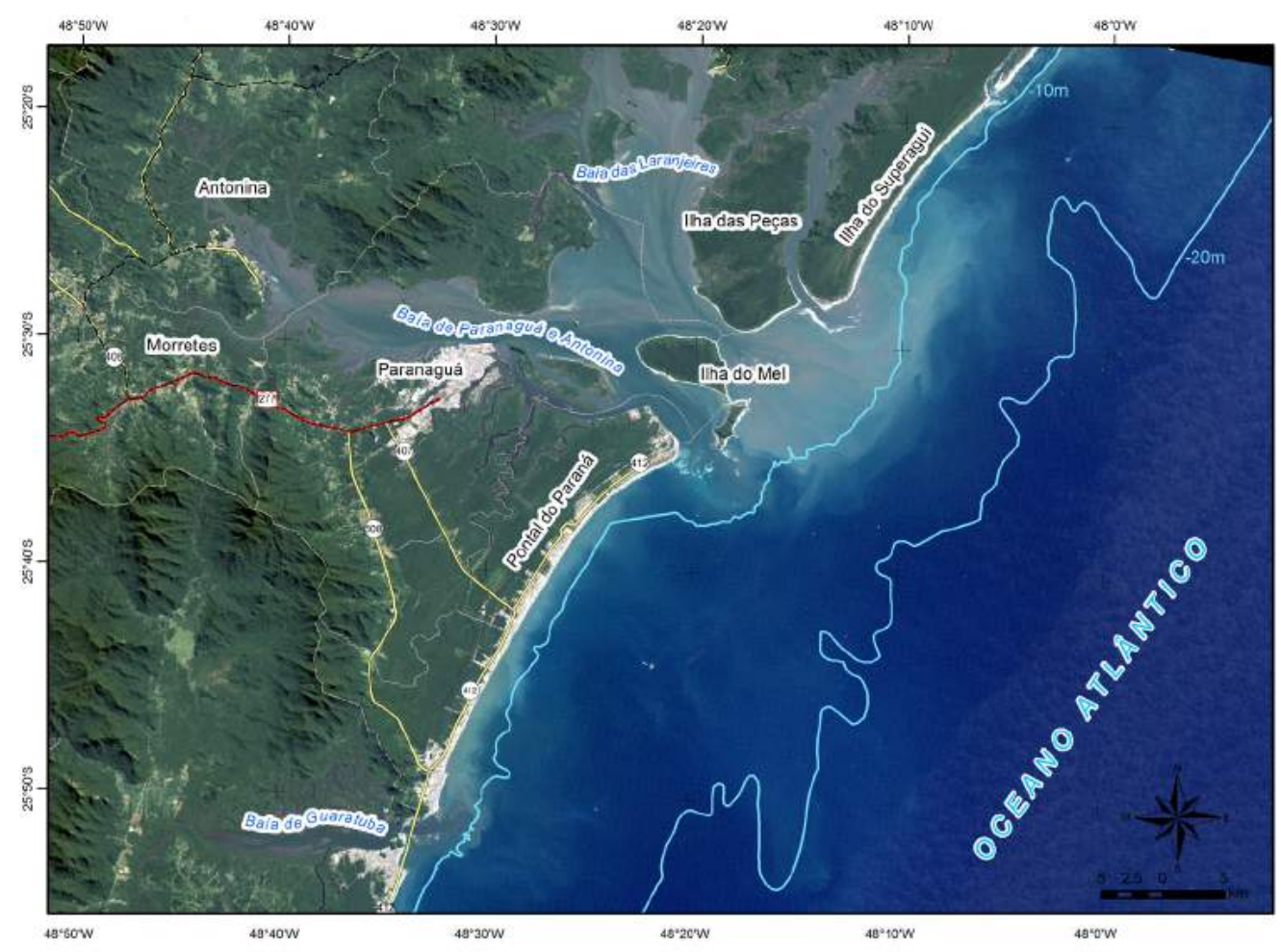

Figura 1. Detalhes da Área de Estudo. Fonte: Imagem cor verdadeira de Landsat -8..

Figure 1. Details of the study area. Source: True color image of Landsat-8. 
conservação existentes dentro da região estuarina.

Dentre os diversos usos e atividades desenvolvidas no CEP e na plataforma rasa destacam-se os canais de navegação $(\mathrm{CN})$ de pequenas embarcaçóes, a existência do canal da Galheta utilizada para a entrada e saída de grandes navios devido às atividades portuárias, as áreas especiais de pesca e cultivo artesanal (PA), as atividades de dragagem do canal da Galheta (AD), áreas de fundeio $(\mathrm{AF})$ de navios, a presença de unidades de conservação (UCs) e suas zonas de amortecimento (ZAs), áreas de influência dos empreendimentos costeiros (Área Diretamente Afetada - ADA, Área de Influência Direta - AID, Área Influência Indireta - AII) e áreas de lazer e turismo.

\section{Base de dados}

Os dados utilizados neste trabalho resultam do Termo de Compromisso firmado entre o Ministério Púbico Estadual do Paraná (MPPR) e a Universidade Federal do Paraná (UFPR); e também por meio do convênio entre o Centro de Estudos do Mar (CEM/ UFPR) e a Administração dos Portos de Paranaguá e Antonina (APPA), intermediada pela Fundação da Universidade Federal do Paraná (FUNPAR) ao longo do ano de 2012. Todos os dados ambientais provenientes do Termo de Compromisso, de zoneamento e licenciamento mantidos pelo Ministério Público através da Coordenadoria Regional da Bacia Litorânea (MP-CRBL) e Centro de Apoio Técnico à Execução - Núcleo de Inteligência (CAEx-NI) foram levantados através do procedimento administrativo MPPR n0046.15.074.223-0: Projeto Licenciamento Integrado - PROLIN. Na totalidade foram disponibilizadas aproximadamente 500 camadas de informação, dos quais 31 foram considerados pertinentes para este trabalho. A base de dados do convênio APPA/CEM é originária de relatórios e documentos existentes na APPA, de estudos acadêmicos e relatórios disponíveis na biblioteca do Centro de Estudos do Mar (CEM/UFPR), bem como docu- mentos relativos ao convênio entre essas instituiçóes entre os anos de 1996 e 2003. As atividades e os usos identificados para a análise foram divididos em duas seçôes, sendo elas áreas de proteçôes ambientais, de usos sociais, turísticos e ecológicos e as áreas de infraestrutura de uso portuário e de uso industrial; dessa forma foi possível agrupar as camadas de informação por familiaridade no uso do território.

\section{Áreas de proteçáo ambiental, de usos sociais, turísticos e ecológicos}

Para a análise espacial dos diferentes usos e ambientes se faz necessária uma definição da área a ser espacializada bem como dos critérios utilizados dentro de cada plano de informação. Neste caso, são apresentados os conceitos utilizados para a definiçáo do espaço considerado; a justificativa associada do porquê de utilização da camada de informação escolhida; a definição da área de acordo com instrumentos legais ou definiçóes para referência; e a definição de temporalidade e razão.

\section{Lazer e turismo}

Conceito utilizado: Atividade econômica que desempenha um papel social de bem-estar e entretenimento para a sociedade. Sáo importantes para a atividade econômica do local e agregam valor não calculável à região através de sítios culturais e paisagísticos.

Importância na análise: Atividade econômica relevante. Diretrizes nas tomadas de decisóes quanto à proteção e manutenção dos ecossistemas e no planejamento de desenvolvimento sustentável.

Definição da área: Baseado no Atlas de Sensibilidade Ambiental ao Óleo da Bacia Marítima de Santos (MMA, 2007), foram considerados pontos representativos de uso recreacional, turístico e sítios históricos e culturais.

emporalidade: Sazonal. A atividade foi considerada sazonal pois são recursos que apesar de estarem fixos no território, o uso dos mesmos náo ocorre no ano inteiro. 


\section{COSTAS}

\section{Unidades de conservaçấo}

Conceito utilizado: Lei do SNUC (Brasil, 2000), compreende no espaço territorial e seus recursos ambientais, incluindo as águas jurisdicionais, com características naturais relevantes, legalmente instituído pelo Poder Público, com objetivos de conservação e limites definidos, sob regime especial de administraçáo, ao qual se aplicam garantias adequadas de proteção.

Importância na análise: Importante papel econômico para a região. São fundamentais para orientar tomadas de decisóes quanto à proteçáo e manutenção dos ecossistemas e no planejamento do desenvolvimento sustentável.

Definição da área: Unidades de conservação de Proteção Integral e de Uso Sustentável (municipal, estadual, federal ou de gestão particular) dentro da área de estudo.

Temporalidade: Permanente. Área delimitada por leis e decretos, existindo pouca ou nenhuma possibilidade de alteração. Além disso, as áreas de proteção ambiental estão constantemente fornecendo serviços ecológicos para o ambiente sendo utilizado pela fauna e flora existente.

\section{Zonas de amortecimento de UCs}

Conceito utilizado: Entorno das unidades de conservação, onde as atividades humanas estão sujeitas a normas e restriçóes específicas, com o propósito de minimizar os impactos negativos sobre a unidade.

Importância na análise: De acordo com a lei do SNUC (Lei n9.9985/200) Art. 25, as unidades de conservaçáo, exceto APA e RPPN, devem possuir uma zona de amortecimento e, quando conveniente, corredores ecológicos.

Definição da área: Delimitadas de acordo com o Plano de Manejo ou caso inexistente, de acordo com a Resolução n428/2010 do CONAMA, estabelecendo um buffer de $3 \mathrm{~km}$ da UC.

Temporalidade: Permanente. Coexistência com as unidades de conservação. As delimitaçôes das zonas
Revista Costas, Vol. 2 (2), 2020

de amortecimento também seguem a regulamentação ambiental através da resolução n 428/2010 do CONAMA.

\section{Áreas de infraestrutura de uso portuário e de uso industrial}

as atividades antrópicas delimitadas como áreas de infraestrutura de uso portuário e de uso industrial também foram caracterizadas pelo conceito, importância para a análise, critérios utilizados na definição da área e pela temporalidade.

\section{Pesca artesanal}

Conceito utilizado: De acordo com a Lei $n^{\circ} 11959 / 2009$, Art $4^{\circ}$, a pesca artesanal são todos os trabalhos de confecção e de reparos de artes e petrechos de pesca, os reparos realizados em embarcaçóes de pequeno porte e o processamento do produto da pesca artesanal.

Importância na análise: Atividade econômica e cultural com papel fundamental na caracterização histórica do Complexo Estuarino de Paranaguá. As 60 comunidades tradicionais, ainda existentes na região, (Andriguetto, 2006) dependem diretamente da atividade para sua subsistência.

Definição da área: Locais utilizados pelas comunidades pesqueiras (total de 43 comunidades) e o número aproximado de pescadores que utilizam a parte interna do CEP para a atividade.

emporalidade: Sazonal. Pelo fato de ser uma prática não contínua e dependente das condiçóes climáticas. Também condicionada aos períodos de defeso para algumas espécies.

\section{Áreas de fundeio}

Conceito utilizado: Sáo locais nos quais os navios podem lançar âncora com alguma norma vigente, previamente regulamentada pela autoridade marítima. Podem ser definidas também por ancoradouros ou fundeadouros. 
mportância na análise: Devido à intensa atividade portuária as áreas de fundeio são um importante indicador de atividade antrópica e industrial da região. Definição da área: Foram considerados os berços de atracação e as áreas de espera para atracagem, externa e interna do estuário.

Temporalidade: Sazonal. São utilizadas em conformidade com algum tipo de demanda portuária. Ou seja, diariamente essas áreas são ocupadas e desocupadas pelos navios que as utilizam como zona de espera para a atracaçáo no porto ou para carga e descarga (no caso dos berços de atracaçáo).

\section{Canais de navegação}

Conceito utilizado: Rotas de passagem utilizadas para o deslocamento de embarcaçóes. Estes canais podem possuir diferentes profundidades dependendo das condiçóes hidroviárias.

Importância na análise: Por serem diariamente utilizados por diversos atores do litoral do Paraná (turismo, pesca, recreação, atividade portuária, comércio, etc), são considerados uma atividade de uso frequente.

Definiçâo da área: Considera-se aqueles mais utilizados dentro da Baía de Paranaguá e Antonina e Baía das Laranjeiras, tanto os para navegação de navios e grandes embarcaçóes, como secundários utilizados por pescadores, barcas de porte médio, etc.

Temporalidade: Sazonal. Sua utilização varia de acordo com a demanda dos setores para que sejam utilizados; de acordo com as condiçôes climáticas podendo inviabilizar a navegaçáo; e também por não existir um padrão temporal de uso.

\section{Dragagem}

Conceito utilizado: As áreas que foram exercidas sob o "ato de retirada de material do leito dos corpos d'água, com finalidade específica". Ainda, definiu-se Dragagem de Implantação: aquela executada para implantação, ampliação ou aprofundamento de canais de navegação, bacias de evoluçáo e em outras obras ou serviços de engenharia em corpos de água; e Dragagem de Manutenção: aquela executada para restabelecer total ou parcialmente as condiçóes originalmente licenciadas.

Importância na análise: Por tratar-se de atividades ambientalmente impactantes e estabelecidas por normas específicas, essas áreas são bons indicativos de atividades antrópicas.

Definição da área: Para a análise, o trecho considerado com presença de obras de dragagem, foi aquele que atualmente passa por processo de aprofundamento de cota. Ele se inicia no Porto de Paranaguá e prolonga-se até a plataforma rasa adjacente à Ilha do Mel. Temporalidade: Sazonal. Depende de uma necessidade ambiental de manutenção da profundidade (ou o aprofundamento) e por ser uma atividade variável na escala de tempo.

\section{Parques aquícolas}

Conceito utilizado: Espaço físico contínuo em meio aquático, delimitado, que compreende um conjunto de áreas aquícolas afins, em cujos espaços físicos intermediários podem ser desenvolvidas outras atividades compatíveis com a prática da aquicultura (MPF, 2018).

Importância na análise: Trata-se de iniciativa do Ministério da Pesca e Aquicultura na busca de um aprimoramento no planejamento e no gerenciamento da maricultura brasileira numa escala municipal, os PLDM foram instituídos oficialmente através da Instruçáo Normativa SEAP n ${ }^{\circ} 17$ de 22 de setembro de 2005.

Definição da área: Definido pelo Plano Local de Desenvolvimento da Maricultura no Paraná, os parques aquícolas foram demarcados de acordo com a favorabilidade entre a espécie a ser cultivada (bijupirá, mexilhão, ostra-do-mangue, ostra-japonesa, Kappaphycus e vieira) e nos seis sistemas de cultivo avaliados (balsas, mesas, long-lines de superfície e de meia água, tanques-rede de pequeno e de grande volume e tanques-rede submergíveis). 


\section{COSTAS}

Temporalidade: Permanente. Trata-se de uma iniciativa governamental e fixa, assim como mencionado, através da Instrução Normativa SEAP n ${ }^{\circ} 17$ de 22 de setembro de 2005.

\section{Descarte ACE20}

Conceito utilizado: Local previamente autorizado pelos órgáos competentes para descarte do material oriundo da dragagem de manutenção dos berços. Denominada ACE 20, local autorizado pela Marinha. Obteve manifesto favorável da Autoridade Marítima, através da Capitania dos Portos do Paraná, para despejo dos sedimentos dragados dos canais dos Portos Organizados de Paranaguá e Antonina, descrito no Ofício $\mathrm{N}^{\circ} 1153 / \mathrm{CPPR}-\mathrm{MB}$.

Importância na análise: A área externa ACE-20 conflui diversos impactos físicos, biológicos e químicos como resultado das operaçóes. Trata-se de local modificado por açóes antrópicas com finalidades industriais-portuários.

Definição da área: Definido pelo Planejamento Estratégico da Infraestrutura Marítima dos Portos do Paraná (PEIM-PR), a área externa de despejo de material dragado, ACE 20, corresponde a uma área circular com raio de 1 milha náutica $(1.852 \mathrm{~m})$ e centro nas coordenadas: $-48^{\circ} 08^{\prime} \mathrm{S}$ e $-25^{\circ} 40^{\prime} \mathrm{W}$.

Temporalidade: Permanente. A área é usada desde 2006 para diferentes atividades de descarte de material. Sendo assim, local de contínuo uso com a autorização da Capitania dos Portos Organizados de Paranaguá e Antonina, órgáo superior da Autoridade Marítima.

\section{Influência de empreendimentos}

Conceito utilizado: Definiu-se no Art. $5^{\circ}$ da Resoluçáo CONAMA 01/86, algumas diretrizes para a delimitação das áreas de influência de empreendimentos potencialmente impactantes. Destaca-se: "III - Definir os limites da área geográfica a ser direta ou indiretamente afetada pelos impactos, denominada área de influência do projeto, considerando, em todos os casos, a bacia hidrográfica na qual se localiza".

Importância na análise: A importância de incluir esses polígonos no trabalho se dá por se tratar de fronteiras invisíveis de regióes de impacto industrial-portuário; muitas vezes negligenciadas por tomadores de decisôes e desconhecida pelas comunidades.

Definição da área: Foram delimitadas de acordo com o que está disponibilizado nos Estudos Ambientais fornecidos por cada empresa, sendo que cada uma delas definiu-as com próprios critérios para o meio biológico, socioeconômico e físico. Utilização apenas das Áreas de Influência Direta de 6 empreendimentos do município de Pontal do Paraná, previstos para a composição do Condomínio do Complexo Portuário de Pontal do Paraná.

Temporalidade: Permanente. Foram delimitadas como fruto de estudos prévios pelos empreendedores (para os ambientes biológico, social e físico). Além disso, as obras de infraestrutura que elas bordeiam, depois de construídas, são permanentes no espaço e paisagem do território.

\section{Mapeamento de conflitos}

A classificação do CEP e da plataforma rasa foi feita posteriormente a uma padronizaçáo do total da área a ser estudada. Estabelecida uma zona fixa de trabalho de $6417,4 \mathrm{~km}^{2}$ compreendida entre 48" 50 ' W a 47 " 90 ' W e 25 " 60 ' S a 25"10' S, as camadas foram trabalhadas e calculadas quando presentes dentro desta zona fixada (figura 1).

A álgebra de mapas foi utilizada na integração das variáveis para identificação de zonas de conflito devido a sobreposição das atividades antrópicas na área de estudo. Para a análise e integração foi necessária uma reclassificação dos atributos existentes nas camadas de informaçóes com novos valores.

Assim, por meio da reclassificação das áreas, foi utilizada a técnica da tabulação cruzada, que é capaz de 
Miura \& Noernberg

integrar variáveis e pode ser realizada por superposição de mapas (Tomlin, 1983). A partir disto, com os novos valores atribuídos, utilizou-se as fórmulas operacionais (Eq. 1 e Eq. 2). As etapas metodológicas empregadas para a obtenção do mapa de conflitos e áreas de sobreposição de atividades são apresentadas na figura 2. Com a utilização da base de dados consoante ao uso do software ArcGis, da tabulação cruzada e da álgebra de mapas, o resultado final é definido.

O Mapa de Conflitos e a porcentagem de áreas de proteção atingidas são definidas, respectivamente, por:

$$
\begin{aligned}
& \text { Mapadeconflitos }=(\text { Variável1 } * \text { Peso } 1)+(\text { Variável2 } * \text { Peso } 2) \\
& +(\text { Variável3 } * \text { Peso } 3)+\ldots(\text { Variável7 } * \text { Peso } 7) \quad \text { Eq. (1) }
\end{aligned}
$$

onde Variável é cada atividade definida e o Peso ${ }_{n}$ é o Grau de Impacto definido na próxima seção.
Porcentagem $=($ ÁreasProteção $)-($ VariávelX $) * 100$

Eq. (2)

onde ÁreasProteção são camadas de informação de todas as Unidades de Conservação ou de todas as Zonas de Amortecimento e VariávelX é cada atividade definida na seção 2.2.2 Áreas de Infraestrutura de Uso Portuário e de Uso Industrial.

\section{Grau de impacto}

Para as atividades e os usos antrópicos, foram quantificados seus valores de Grau de Impacto (GI) sobre as unidades de conservação e suas zonas de amortecimento. A metodologia para a valoração foi adotada com base no Decreto no 6.848/2009 no qual prevê medidas para que o IBAMA (Instituto Brasileiro de Meio Ambiente e dor Recursos Naturais Renováveis) estabeleça o grau de impacto a partir de estudo pré-

\section{Fluxograma Metodológico}

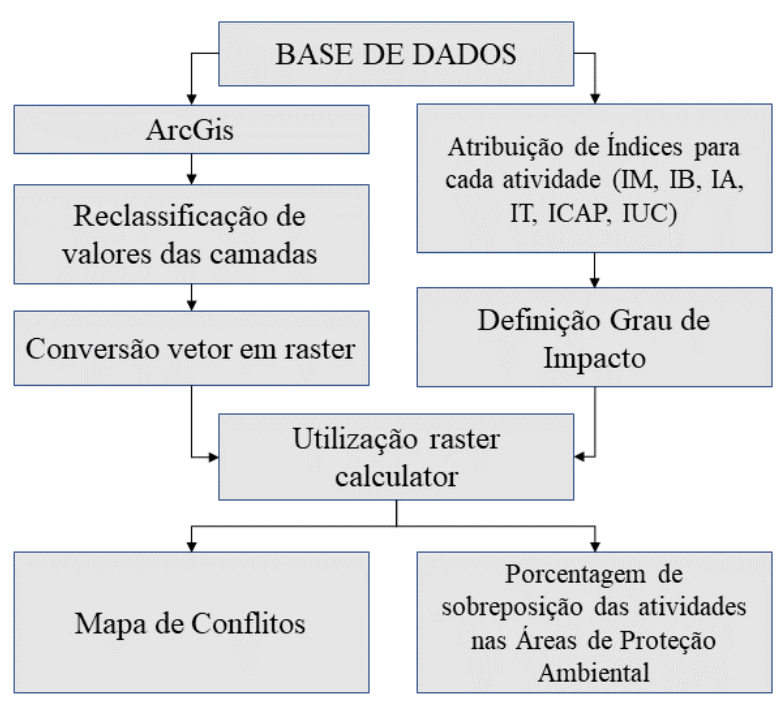

Figura 2. Etapas metodológicas para a identificação das zonas de conflitos e porcentagem de sobreposição das atividades sobre as áreas de proteção.

Figure 2. Methodological steps for identifying conflict zones and percentage of activities over protected areas. 


\section{COSTAS}

vio de EIA/RIMA (Estudo de Impacto Ambiental/ Relatório de Impacto Ambiental) em que considera, exclusivamente, os impactos ambientais negativos sobre o meio ambiente, para a fixação da compensação ambiental que trata o art. 36 da Lei no 9.985 de 2000.

O Governo Federal, em 14 de maio de 2009, editou o Decreto no 6.848, modificando o art. 31 do Decreto $n^{\circ} 4340 / 2002$ e incluindo neste diploma os arts. 31-A e 31-B.

Art. 31-A. O Valor da Compensação Ambiental - CA será calculado pelo produto do Grau de Impacto - GI com o Valor de Referência - VR, de acordo com a fórmula a seguir: $\mathrm{CA}=\mathrm{VR} \times \mathrm{GI}$, onde: $\mathrm{CA}=$ Valor da Compensação Ambiental; $\mathrm{VR}$ = somatório dos investimentos necessários para implantação do empreendimento, não incluídos os investimentos referentes aos planos, projetos e programas exigidos no procedimento de licenciamento ambiental para mitigação de impactos causados pelo empreendimento, bem como os encargos e custos incidentes sobre o financiamento do empreendimento, inclusive os relativos às garantias, e os custos com apólices e prêmios de seguros pessoais e reais; e GI = Grau de Impacto nos ecossistemas, podendo atingir valores de 0 a $0,5 \%$. (BRASIL, 2002)

Portanto, foi aplicado apenas a fórmula de cálculo para o Grau de Impacto nos ecossistemas para cada atividade, sem definição do valor final de compensação ambiental. O GI varia entre 0 e $0,5 \%$, definido por:

$$
G I=I S B+C A P+I U C, \quad E q \cdot(3)
$$

onde ISB é o impacto sobre a biodiversidade; CAP o comprometimento de área prioritária; e IUC a influência em Unidades de Conservação. O ISB é calculado pela relação:
Revista Costas, Vol. 2 (2), 2020

$$
I S B=\frac{I * I B(I A+I T)}{140}, \quad E q . \text { (4) }
$$

onde IM é o índice de magnitude; IB é o índice de biodiversidade; IA é o índice de abrangência; e IT é o índice de temporalidade.

$\mathrm{O}$ ISB varia entre 0 e $0,25 \%$, e tem como objetivo contabilizar os impactos do empreendimento diretamente sobre a biodiversidade na sua área de influência direta e indireta. Ainda, o CAP contabiliza os efeitos do empreendimento sobre a área prioritária em que se insere. Isto é observado fazendo a relação entre a significância dos impactos frente às áreas prioritárias afetadas (BRASIL, 2009). O CAP varia entre 0 e $0,25 \%$. O comprometimento de área prioritária é calculado através de:

$$
C A P=\frac{I * I C A P * I T}{70}, \quad E q . \text { (5) }
$$

onde IM é o Índice Magnitude; o ICAP é o índice de comprometimento de área Prioritária; e IT é o índice de temporalidade.

O IUC varia de 0 a $0,15 \%$, avaliando a influência do empreendimento sobre as unidades de conservaçáo ou suas zonas de amortecimento, sendo que os valores podem ser considerados cumulativamente até o valor máximo de $0,15 \%$, de acordo com os critérios pré-estabelecidos, descritos no tabela 1.

Os índices utilizados no cálculo do Grau de Impacto foram retirados do Decreto $n^{\circ} 6.848$.

\section{Índice de Magnitude (IM)}

O IM varia de 0 a 3 e avalia de forma integrada a existência e a relevância dos impactos ambientais negativos significativos sobre os diversos aspectos ambientais associados ao empreendimento (tabela 2).

\section{Índice Biodiversidade (IB)}

O IB varia de 0 a 3 e avalia o estado da biodiversidade previamente à implantaçáo do empreendimento (tabela 3). 
Tabela 1. Critérios para definição do Índice de Influência em Unidades de Conservação (IUC).

Table 1. Criteria for defining the Conservation Units Influence Index (IUC).

\section{IUC}

G1: Parque (nacional, estadual e municipal), reserva biológica, estação ecológica, refúgio de vida silvestre e monumento natu$\mathrm{ral}=0,15 \%$;

G2: Florestas (nacionais e estaduais) e reserva de fauna $=0,10 \%$;

G3: Reserva extrativista e reserva de desenvolvimento sustentável $=0,10 \%$;

G4: Área de proteção ambiental, área de relevante interesse ecológico e reservas particulares do patrimônio natural = 0,10\%; e

G5: Zonas de amortecimento de unidades de conservaçáo $=0,05 \%$.

Fonte: Brasil (2009).

\begin{tabular}{|c|l|}
\multicolumn{2}{|c|}{$\begin{array}{c}\text { Tabela 2. Critérios para definição do Índice de Magnitude (IM). } \\
\text { Table 2. Criteria for defining the Magnitude Index (IM). }\end{array}$} \\
\hline Valor & \multicolumn{1}{c|}{ Atributo } \\
\hline 0 & Ausência de impacto ambiental significativo negativo \\
\hline 1 & Baixa magnitude do impacto ambiental negativo em relação ao comprometimento dos recursos ambientais \\
\hline 2 & Média magnitude do impacto ambiental negativo em relação ao comprometimento dos recursos ambientais \\
\hline 3 & Alta magnitude do impacto ambiental negativo \\
\hline Fonte: Brasil (2009).
\end{tabular}

\begin{tabular}{|c|l|}
\multicolumn{2}{|c|}{$\begin{array}{c}\text { Tabela 3. Critérios para definição do Índice de Biodiversidade (IB). } \\
\text { Table 3. Criteria for defining the Biodiversity Index (IB). }\end{array}$} \\
\hline Valor & \multicolumn{1}{c}{ Atributo } \\
\hline 0 & Biodiversidade se encontra muito comprometida \\
\hline 1 & Biodiversidade se encontra medianamente comprometida \\
\hline 2 & Biodiversidade se encontra pouco comprometida \\
\hline 3 & Área de trânsito ou reprodução de espécies consideradas endêmicas ou ameaçadas de extinção \\
\hline Fonte: Brasil (2009).
\end{tabular}




\section{COSTAS}

\section{Índice Abrangência (IA)}

De acordo com o decreto, o IA varia de 1 a 4 e avalia a extensão espacial de impactos negativos sobre os recursos ambientais. Em casos de empreendimentos lineares o IA será avaliado em cada microbacia separadamente, ainda que o trecho submetido ao processo de licenciamento ultrapasse os limites de cada microbacia (tabela 4).

\section{Índice Temporalidade (IT)}

O IT varia de 1 a 4 e se refere à resiliência do ambiente ou bioma em que se insere o empreendimento (tabela 5). Avalia a persistência dos impactos negativos do empreendimento.

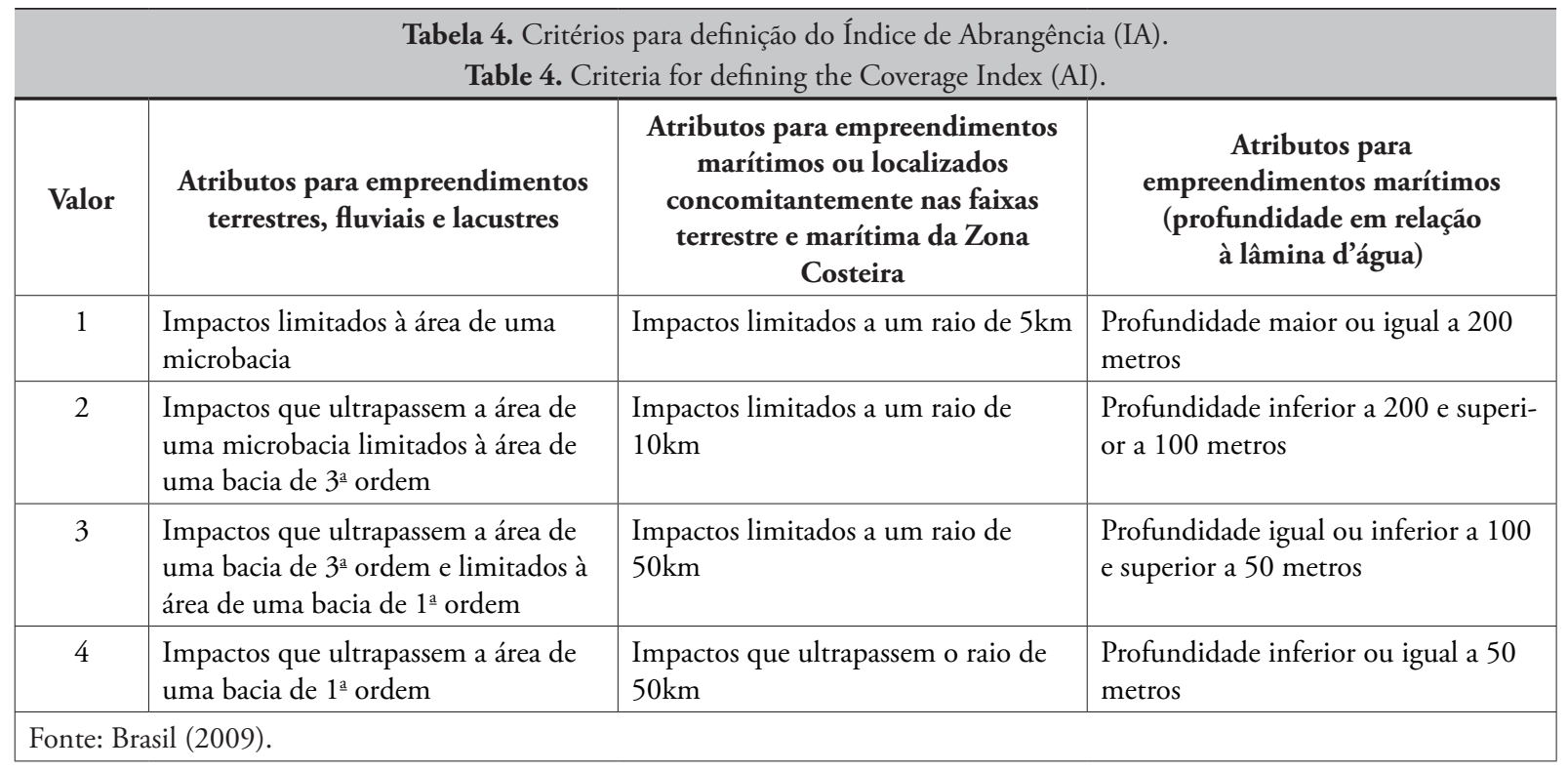

\begin{tabular}{|c|l|}
\multicolumn{2}{|c|}{$\begin{array}{c}\text { Tabela 5. Critérios para definição do Índice de Temporalidade (IT). } \\
\text { Table 5. Criteria for defining the Temporality Index (IT). }\end{array}$} \\
\hline Valor & \multicolumn{1}{c|}{ Atributo } \\
\hline 1 & Imediata: até 5 anos após a instalação do empreendimento; \\
\hline 2 & Curta: superior a 5 e até 15 anos após a instalação do empreendimento; \\
\hline 3 & Média: superior a 15 e até 30 anos após a instalação do empreendimento; \\
\hline 4 & Longa: superior a 30 anos após a instalação do empreendimento. \\
\hline Fonte: Brasil (2009).
\end{tabular}


Índice Comprometimento de Áreas Prioritárias (ICAP)

O ICAP varia de 0 a 3 e avalia o comprometimento sobre a integridade de fração significativa da área prioritária impactada pela implantação do empreendimento, conforme mapeamento oficial de áreas prioritárias aprovado mediante ato do Ministro de Estado do Meio Ambiente ${ }^{1}$ (tabela 6).

Logo, com a definição do Grau de Impacto, é possível estabelecer níveis de influência (ou impacto) das atividades com o ambiente. Neste caso foram adotadas as normas já existentes pela legislação ambiental para melhor se aproximar da realidade.

Após a definição dos pesos (ou GI), as camadas de cada polígono foram reclassificadas com a finalida- de de igualar os seus valores, ou seja, admitindo não existir distinção espacial para o cálculo com álgebra de mapas. Posteriormente, todos os polígonos das atividades foram transformados em formato raster. A Eq. 1 foi aplicada com as 7 atividades para gerar as principais áreas de conflitos com base na sobreposição dos impactos. Para melhorar a qualidade visual dos resultados o método de convolução cúbica e um filtro de média foram aplicados.

Em uma análise qualitativa dos conflitos, adotamos a variação entre Baixo Conflito (0\%) e Alto Conflito $(0,5 \%)$ de acordo com a Eq. (3). O menor grau de impacto está relacionado ao nível de Baixo Conflito e o maior grau de impacto relacionado com o nível de Alto Conflito.

\section{Resultados}

A partir das definiçóes e caracterizaçóes das atividades, obteve os índices necessários para o cálculo do GI (IM, IB, IA, IT, ICAP e IUC) e GI para cada atividade (tabelas 7 e 8). As áreas de infraestrutura de uso portuário e de uso industrial e as áreas de proteção ambiental, de uso social, turístico e ecológico foram espacializadas e agrupadas em 4 cartogramas de acordo com a temporalidade (figura 3).

Os valores do GI variaram entre $0,22 \%$ e máximo de $0,36 \%$.

Após a espacialização das atividades, o processo de álgebra de mapas foi capaz de multiplicar cada va-

Tabela 6. Critérios para definição do Índice de Comprometimento de Áreas Prioritárias (ICAP). Table 6. Criteria for defining the Priority Areas Impairment Index (ICAP).

\begin{tabular}{|c|l|}
\hline Valor & \multicolumn{1}{c|}{ Atributo } \\
\hline 0 & $\begin{array}{l}\text { Inexistência de impactos sobre áreas prioritárias ou impactos em áreas prioritárias totalmente sobrepostas a unidades de } \\
\text { conservação. }\end{array}$ \\
\hline 1 & Impactos que afetem áreas de importância biológica alta \\
\hline 2 & Impactos que afetem áreas de importância biológica muito alta \\
\hline 3 & $\begin{array}{l}\text { Impactos que afetem áreas de importância biológica extremamente alta ou classificadas como insuficientemente conhe- } \\
\text { cidas }\end{array}$ \\
\hline Fonte: Brasil (2009).
\end{tabular}

\footnotetext{
${ }^{1}$ Mapa de Áreas Prioritárias para a Conservação, Utilização Sustentável e Repartição de Benefícios da Biodiversidade Brasileira
} definida pelo Ministério do Meio Ambiente. Disponível em: http://www.mma.gov.br/estruturas/chm/_arquivos/maparea.pdf. 


\section{rig \\ COSTAS}

Tabela 7. Atribuiçōes dos Índices de Magnitude (IM), Índices de Biodiversidade (IB), Índices de Abrangência (IA), Índices de Temporalidade (IT), Índices de Comprometimento de Áreas Prioritárias (ICAP) e a Influência em Unidades de Conservação (IUC).

Table 7. Attributions of Magnitude Indices (IM), Biodiversity Indices (IB), Scope Indices (IA), Temporality Indices (IT), Priority Area Commitment Indices (ICAP) and the Influence on Conservation Units (IUC).

\begin{tabular}{|l|c|c|c|c|c|c|}
\hline \multicolumn{1}{|c|}{ Atividades } & IM & IB & IA & IT & ICAP & IUC \\
\hline Pesca Artesanal & 1 & 3 & 4 & 2 & 3 & 0,15 \\
\hline Áreas de Fundeio & 1 & 3 & 4 & 2 & 0 & 0,15 \\
\hline Canais de Navegação & 1 & 3 & 4 & 2 & 0 & 0,15 \\
\hline Dragagem & 2 & 3 & 4 & 2 & 3 & 0,05 \\
\hline Parques Aquícolas & 1 & 3 & 4 & 2 & 3 & 0,15 \\
\hline Descarte ACE20 & 2 & 2 & 4 & 2 & 3 & 0 \\
\hline $\begin{array}{l}\text { Área de Influência Direta } \\
\text { de Empreendimentos }\end{array}$ & 1 & 2 & 3 & 2 & 3 & 0,15 \\
\hline
\end{tabular}

Tabela 8. Valores de graus de impacto calculados para cada atividade analisada. Table 8. Values of degrees of impact calculated for each activity analyzed.

\begin{tabular}{|c|c|}
\hline Atividades & Grau de Impacto \\
\hline Pesca Artesanal & 0,30 \\
\hline Áreas de Fundeio & 0,32 \\
\hline Canais de Navegação & 0,25 \\
\hline Dragagem & 0,35 \\
\hline Parques Aquícolas & 0,36 \\
\hline Área de Influência Direta de Empreendimentos & 0,36 \\
\hline
\end{tabular}

riável (atividade) por seu peso (Grau de Impacto), para estabelecer as zonas mais conflituosas de acordo com o grau de sobreposição das camadas. As zonas com maior presença de conflito estáo coloridas em vermelho e com menor presença, em azul (figura 4).

A fim de quantificar a porcentagem de sobreposição das atividades às UCs da zona costeira e marinha e às ZAs, foi calculada a área total das feiçóes que resultaram da interseção (Eq. 2). Os resultados obtidos podem ser vistos na tabela 9 .

Um total de 19,21\% do espaço delimitado para as unidades de conservação (incluindo sobre terra e mar) possui sobreposição com outras atividades. Ain- da, 33,27\% das zonas de amortecimento definidas para a proteçáo e conservaçáo dos recursos naturais das unidades de conservação também se sobrepóem com outras atividades dentro do estuário. A AID dos empreendimentos de Pontal do Paraná foi aquela que mais se sobrepôs às UCs, afetando a APA de Guaraqueçaba, Estação Ecológica da Ilha do Mel, Parque Municipal da Ilha da Cotinga, Estação Ecológica do Guaraguaçu, Parque Estadual do Palmito, Parque Municipal da Restinga, Reserva Biológica Bom Jesus e Parque Nacional de Superagui. A sobreposição das unidades de conservaçáo com as principais zonas de conflito é apresentada na figura 5. 

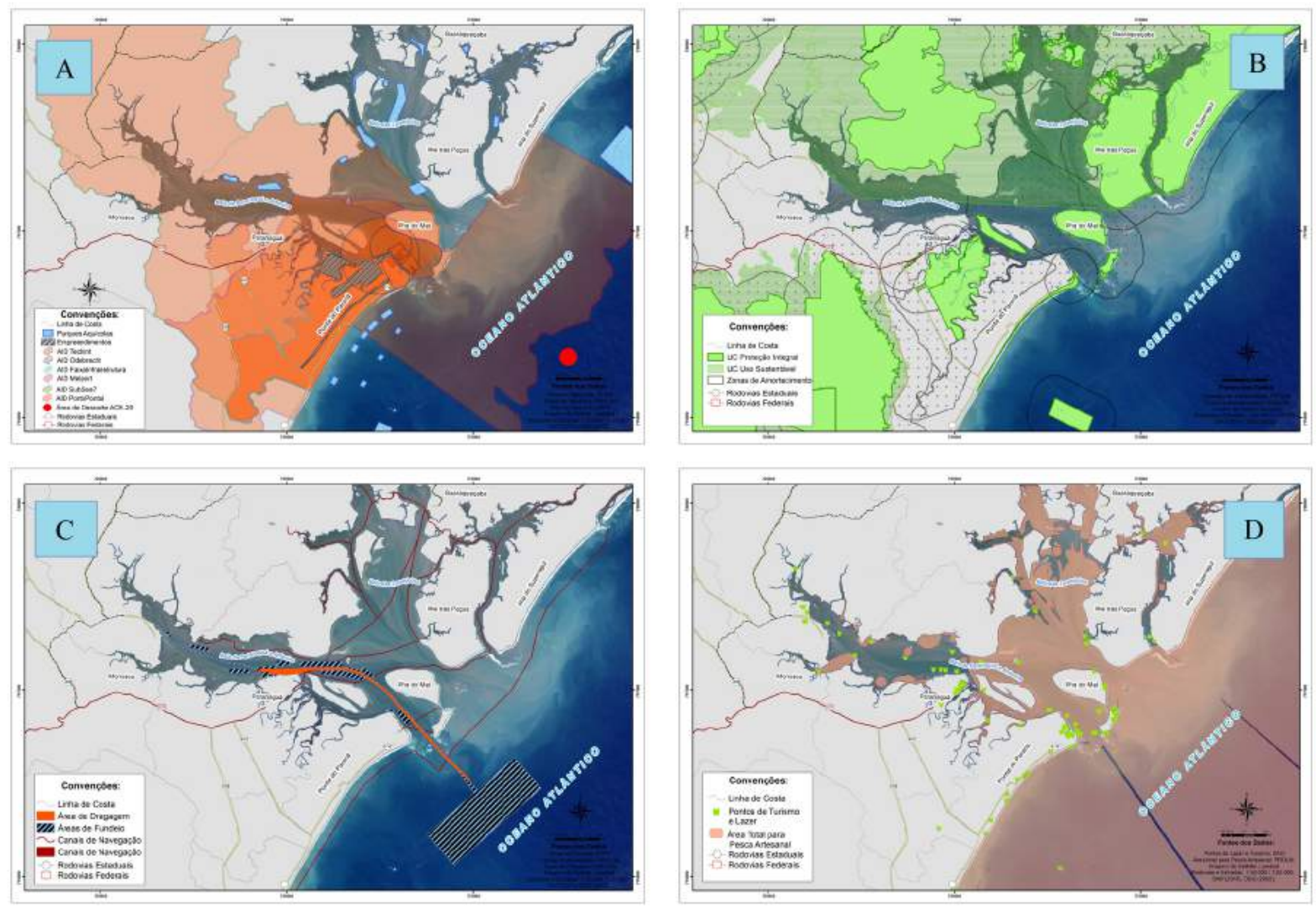

Figura 3. Áreas permanentes de infraestrutura de uso portuário e de uso industrial (A); áreas permanentes de proteção ambiental, de usos sociais, turísticos e ecológicos (B); áreas sazonais de infraestrutura de uso portuário e de uso industrial (C) e áreas sazonais de proteção ambiental, de uso social, turístico e ecológico (D).

Figure 3. Map of permanent areas of infrastructure for port use and industrial use (A); areas of environmental protection, social, tourist and ecological uses (B); areas of infrastructure for port use and industrial use (C) and areas of environmental protection, social, tourist and ecological use (D).

\section{Discussão}

O Complexo Estuarino de Paranaguá está inserido em um hotspot de biodiversidade - de acordo com o Ministério do Meio Ambiente (2002) são regiōes de grande riqueza biológica que estão extremamente ameaçadas - considerado de extrema importância biológica pela Portaria n009 de 2007 do Ministério do Meio Ambiente, com reconhecimento mundial como reserva da biosfera pela ONU (Organização das Naçóes Unidas). Existem mais de 30 unidades de conservação de Uso Sustentável e de Proteção Integral (figura 3) as quais integram um mosaico que garante a conservação e preservação dessas áreas ambientalmente sensíveis.

Todavia, as atividades antrópicas exercidas no continente não se limitam ao espaço geográfico emergente. Os usos para fins industriais e portuários impactam, seja positivamente ou negativamente, o ambiente aquático (figura 3). Grande porção aquáti- 


\section{Fis \\ COSTAS}

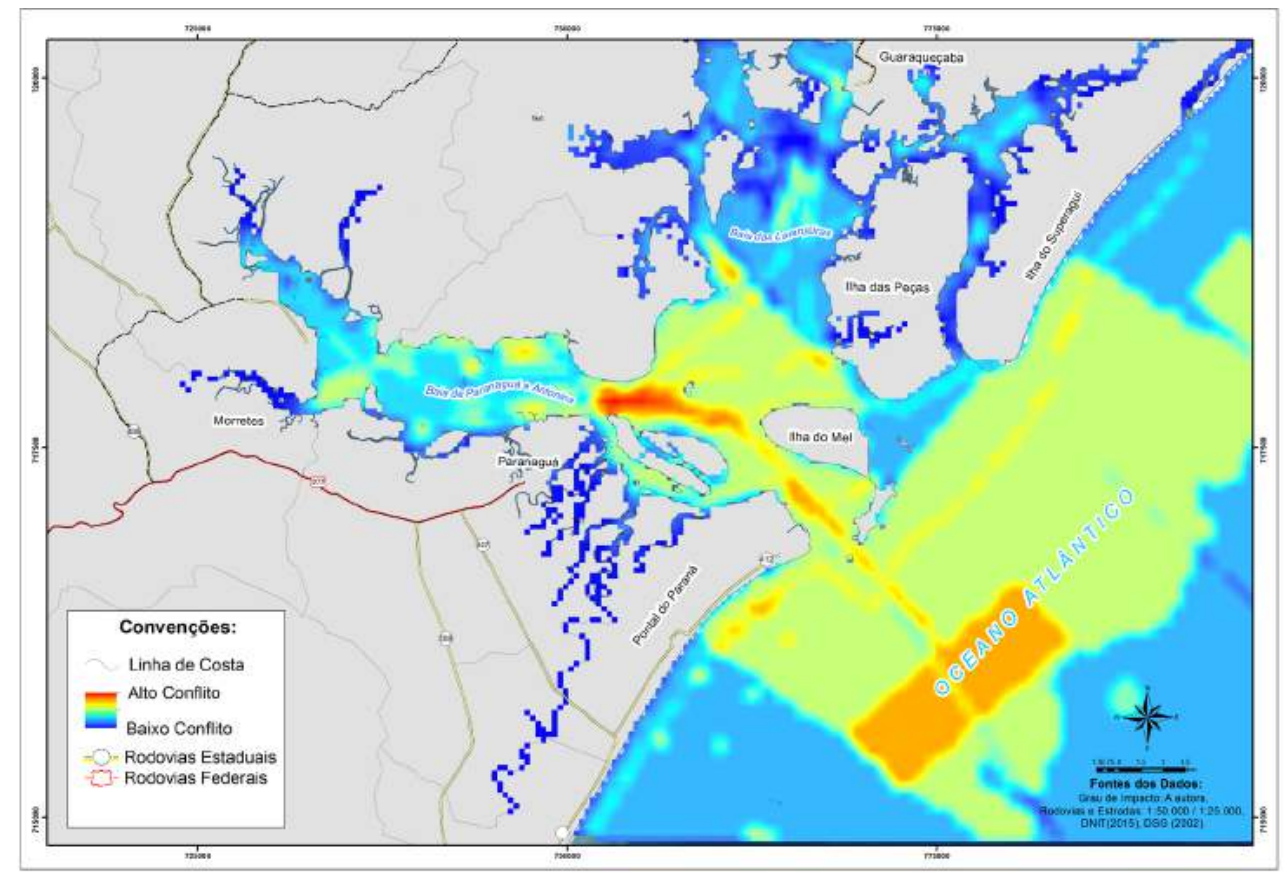

Figura 4. Distribuição das principais áreas de conflitos na porção aquática do CEP e Plataforma Rasa. Figure 4. Distribution of the main conflict areas in the aquatic part of the CEP and shallow platform.

Tabela 9. Áreas de Unidades de Conservação e Zonas de Amortecimento afetadas. Table 9. Areas of protected areas and buffer zones affected.

\begin{tabular}{|l|c|c|c|c|}
\hline \multicolumn{1}{|c|}{ Empreendimento } & $\begin{array}{c}\text { Área UC afetada } \\
\left(\mathbf{k m}^{\mathbf{2}} \mathbf{)}\right.\end{array}$ & $\begin{array}{c}\text { Área ZA afetada } \\
\left(\mathbf{k m}^{\mathbf{2}}\right)\end{array}$ & $\begin{array}{c}\text { Área UC afetada } \\
(\mathbf{\%})\end{array}$ & $\begin{array}{c}\text { Área ZA afetada } \\
(\mathbf{\%})\end{array}$ \\
\hline $\begin{array}{l}\text { Áreas de Influência } \\
\text { Direta }\end{array}$ & 162,28 & 261,93 & 5,67 & 9,09 \\
\hline Parques Aquícolas & 20,26 & 16,70 & 0,70 & 0,58 \\
\hline Descarte ACE-20 & 0 & 0 & 0 & 0 \\
\hline Rotas de Navegaçáo & 70,01 & 100,27 & 2,44 & 3,48 \\
\hline Áreas de Dragagem & 0 & 5,88 & 0 & 0,20 \\
\hline Áreas de Fundeio & 4,91 & 20,68 & 0,17 & 0,71 \\
\hline Área de Pesca Artesanal & 292,04 & 552,59 & 10,21 & 19,19 \\
\hline Total & 549,51 & 958,07 & 19,21 & 33,27 \\
\hline
\end{tabular}




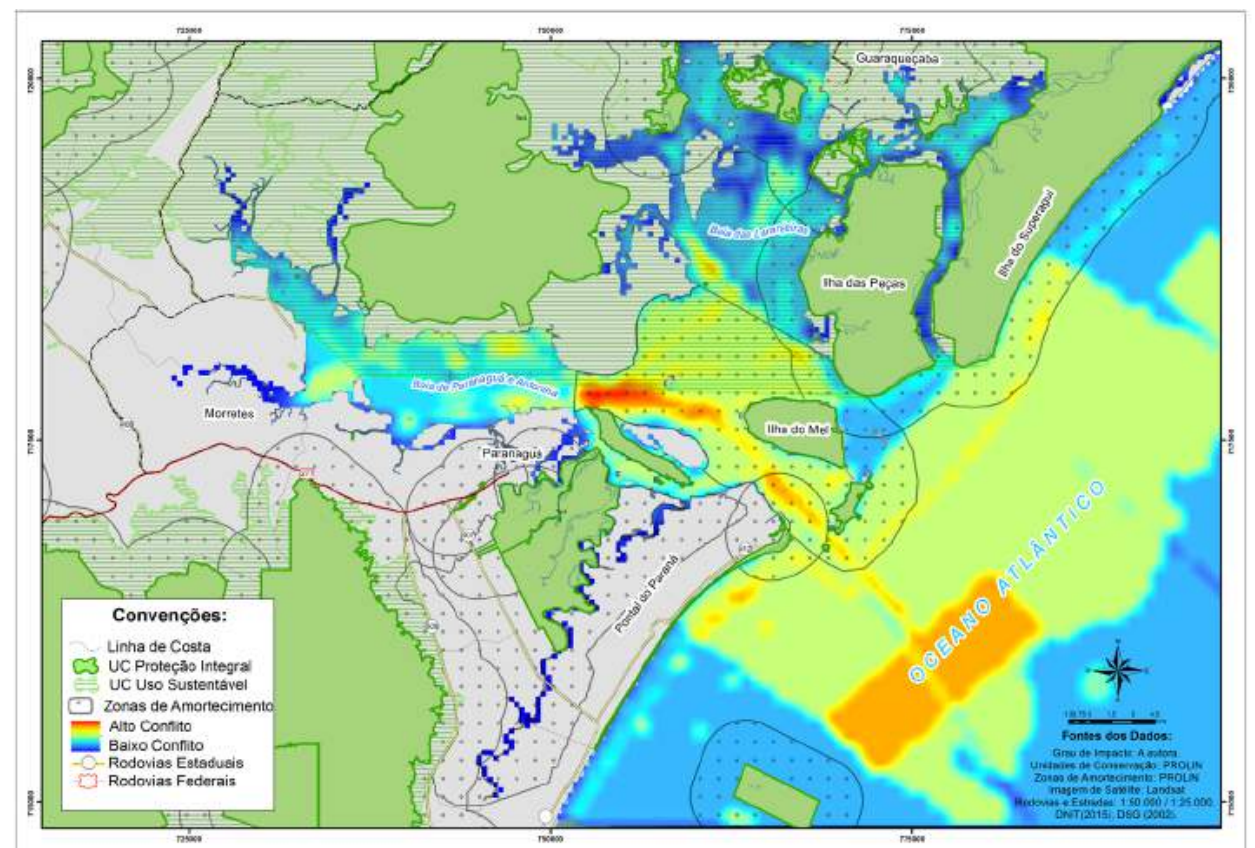

Figura 5. Distribuição das principais áreas de conflitos sobrepostas com as unidades de conservação e respectivas zonas de amortecimento na porção aquática do CEP e plataforma rasa.

Figure 5. Distribution of the main areas of conflict overlapping with the conservation units and respective buffer zones in the aquatic portion of the CEP and shallow platform.

ca do estuário é utilizado para a pesca artesanal, atividade marcante da cultura caiçara, proveniente da mistura de povos indígenas, quilombolas e europeus que até os dias atuais utilizam e dependem deste mesmo habitat (Andriguetto et al., 2006).

$\mathrm{Na}$ concepção de Little (2001), os conflitos socioambientais ocorrem mediante embates entre grupos sociais, com modos diferentes de se inter-relacionar com o ambiente social e natural, surgindo das interações ecológicas entre os diferentes atores sociais e o meio biofísico. Através da tabela 8 é possível perceber as diferentes relaçóes do ser humano com o ambiente e as variações no nivel de impacto que exercem sobre ele.

Devido as diversas interações entre o ser humano e o meio ambiente, muitos países estão fazendo tentativas para gerenciar os conflitos entre os usuários dos recursos costeiros e impedir os danos ambientais (Tuda, 2014). Diversos autores como Venegas-Li (2017), Vigl (2017), (Tuda, 2014) e Gissi (2017) espacializaram e quantificaram o acúmulo de impactos antropogênicos em distintas regiôes. Propostas de metodologias de estudo e análise para subsidiar tomadas de decisão com base no PEM.

O litoral do Paraná é local de sobreposição de territorialidades, com populaçóes e suas reproduçóes culturais e outros espaços destinados à conservação da natureza (Santos \& Quadros, 2016; Pigosso et al., 2018). É notável na porção aquática nos arredores da cidade de Paranaguá altos níveis de conflito (figura 4). As atividades associadas ao uso portuário são aquelas que mais contribuem para o alto nível de conflito, por se sobreporem entre si, mas também à Pesca Artesanal e Rotas de Navegaçáo. Outros locais 


\section{COSTAS}

com níveis mais elevados se encontram nos arredores de Pontal do Sul e na região da Ponto do Poço; porção Sul da Baía das Laranjeiras e na Plataforma Externa (predominantemente nas áreas definidas como fundeadouro de navios de grande porte). Outros locais que apresentaram níveis mais elevados de conflitos e que devem ser destacados, estão localizados dentro da Baía das Laranjeiras, em frente a Ilha das Peças e na margem leste de Pontal do Paraná, na regiāo costeira do município.

Em termos de quantificação das áreas atingidas, observamos que as atividades estudadas também se sobrepóem dentro dos limites definidos para as UCs (figura 5). Os resultados mostram que $549 \mathrm{~km}^{2}$ das UC são afetados pelos empreendimentos analisados, assim como mais de $950 \mathrm{~km}^{2}$ das ZA. Estas sobreposiçóes representam $19,21 \%$ de toda a área das unidades e 33,27\% das ZA (tabela 9). A unidade de conservação mais afetada é a APA de Guaraqueçaba (sobreposta com AIDs, parque aquícola, rotas de navegação, áreas de fundeio e zonas de pesca) e isso se deve ao fato de possuir parte da sua área sobre a água, diferentemente das demais UCs.

Aqui, mencionamos certas deficiências deste trabalho como a necessidade de um forte embasamento para atribuição dos índices; padronização entre as camadas com a mesma referência de coordenadas geográficas; objetividade e clareza do espaço a ser estudo e mapemaento de alvos sensíveis da regiáo.

No Brasil, o arcabouço legislativo para gestáo de áreas marinhas possui amplo embasamento com as seguintes políticas: Decreto $n^{\circ} 74.557 / 1974$ (Co-

\section{Conclusão}

Através do Planejamento Espacial Marinho é possível estabelecer delimitaçóes, normas e diretrizes para que a gestáo das águas se torne eficaz, evitando que a costa e a porção aquática associada se torne uma missão Interministerial para os Recursos do Mar - CIRM; Decreto n 5.377/2005 (Política Nacional para os Recursos do Mar - PNRM); Decreto $n^{\circ}$ 1530/1982 (Convenção das Naçóes Unidas sobre o Direito do Mar - CNUDM); Plano Setorial para os Recursos do Mar (PSRM); Resolução nº 001/97, da CIRM (Sistema Brasileiro de Observação dos Oceanos e Estudos do Clima - GOOS - BRASIL); Lei ${ }^{\circ}$ 6.938/1981 (Política Nacional do Meio Ambiente PNMA), a Política Nacional de Assuntos Antárticos (POLANTAR), o Plano Nacional de Gerenciamento Costeiro (PNGC) (Lei n $\left.{ }^{\circ} 7.661 / 1988\right)$, a Política Nacional para os Recursos do Mar (PNRM); a Lei Estadual n 13.164/2001 (Zona Costeira do Estado do Paraná), que trata, inclusive, dos instrumentos do Plano Estadual de Gerenciamento Costeiro - PEGC (art. 6 ${ }^{\circ}$ ): (i) macrozoneamento da Região do Litoral Paranaense, estabelecido pelo Decreto Estadual $n^{\circ}$ 5040, de 11 de maio de 1989; (ii) sistema de Informaçóes do Gerenciamento Costeiro; (iii) programas de Monitoramento Ambiental; e (iv) planos de Gestão.

Neste contexto, realizada de forma participativa e inclusiva com todos os setores econômicos, sociais e conservacionistas da região, o PEM baseado na legislação brasileira associado com a utilizaçáo de ferramentas SIG, identifica os conflitos existentes e poderia definir os principais alvos de conservação. Ainda, é capaz de compilar informação e mapear a distribuição espacial e temporal e a densidade de atividades humanas importantes na zona de gestão marinha (UNESCO-IOC, 2009).

"caixa de consequências" dos processos desenvolvidos em terra. As áreas protegidas por legislaçóes ambientais no Litoral do Paraná se encontram afetadas pelas atividades desenvolvidas na porção aquática do CEP, 
além de apresentar os seus limites administrativos com níveis de Alto Conflito. Mesmo que a maneira do homem de se interrelacionar com o ambiente seja de diferentes formas, índices próximos de impacto podem ser observados entre eles.

Conclui-se que novas iniciativas para o PEM no local são necessárias, dentre elas: (i) maior detalhamento de todas as atividades realizadas no CEP para melhor aferição da realidade; (ii) diferenciação do grau de impacto dentro de cada atividade e (iii) divisão da porção aquática em diferentes setores de acordo com objetivos estratégicos bem definidos e atores político-sociais identificados. A utilizaçáo de uma referência aprofundada da área de estudo como base, por exemplo o projeto Paraná Mar e Costa (2006), seria

\section{Referência}

Andriguetto Filho J. M.; Chaves, P. T.; Santos, C.; Liberati, S. A. Diagnóstico da pesca no estado do Paraná. A pesca marinha e estuarina do Brasil no início do século XXI: Recursos, tecnologias, aspectos socioeconômicos e institucionais, p. 116-140, 2006.

Aswani, S.; Lauer, M. Incorporating Fishermen's Local Knowledge and Behavior into Geographical Information Systems (GIS) for Designing Marine Protected Areas in Oceania. Human Organization, v. 65, n. 1, p. 81-102, 2006. Disponível em: https://www.jstor. org $/$ stable $/ 44127124$ ? read-now $=1 \&$ seq $=2 \#$ page scan_tab_contents.

Brasil. Decreto n. 4.340, de 22 de agosto de 2002. Regulamenta artigos da Lei no 9.985, de 18 de julho de 2000, que dispóe sobre o Sistema Nacional de Unidades de Conservação da Natureza - SNUC, e dá outras providências. Brasília: DOU de 23/08/2002.

Brasil. Decreto n. 6.848, de 14 de maio de 2009. Altera e acrescenta dispositivos ao Decreto no 4.340, de 22 de agosto de 2002, para regulamentar a compensação ambiental. Brasília: DOU de 14/05/2009.

Brasil. Decreto n. 9.985, de 18 de julho de 2000. Regulamenta o art. 225, $\$ 1$ o, incisos I, II, III e VII da Constituiçáo Federal, institui o Sistema Nacional de importante para fundamentar questóes específicas do local de estudo. Sendo útil como norteador para aplicação de políticas públicas em áreas socioambientais sensíveis.

Desta forma, a espacialização dos conflitos existentes em um local com ampla utilização de diferentes finalidades, é capaz de dar suporte para definir estratégias econômicas; dirigir açôes para políticas públicas e tomadas de decisóes; quantificar impactos em áreas de importância ecológica e áreas ocupadas por populaçóes tradicionais. Ainda, pode ser útil como sinalizador para a mitigaçáo e compensação de impactos ambientais e sociais causados pelas diversas atividades humanas na área de estudo.

Unidades de Conservação da Natureza e dá outras providências. Brasília: DOU de 23/08/2002.

Brasil. Lei $\mathrm{n}^{\circ} 11.959$, de 29 de junho de 2009. Dispóe sobre a Política Nacional de Desenvolvimento Sustentável da Aquicultura e da Pesca, regula as atividades pesqueiras, revoga a Lei $n^{\circ} 7.679$, de 23 de novembro de 1988, e dispositivos do Decreto-Lei no 221, de 28 de fevereiro de 1967, e dá outras providências. Brasília: DOU de 29/06/2009.

Castella, R. M. B.; Castella, P. R.; Figueiredo, D. C. dos S.; Queiroz, S. M. P.(Organizadores). Paraná-Mar e Costa: Subsídios ao Ordenamento das Áreas Estuarina e Costeira do Paraná. Curitiba, 2006. Disponível em: http://pdslitoral.com/subsidios-ao-ordenamento-das-areas-estuarina-e-costeira-do-parana/. Diegues, Antonio Carlos (org.). Enciclopédia Caiçara. 4 vol. São Paulo: Hucitec; Nupaub, 2005.

Fernandes, B. M.; Paulino, E. T.; Fabrini, J. E. Entrando nos territórios do Território. Campesinato e territórios em disputa. São Paulo: Expressão Popular, p. 273302, 2008b.

Gilliland, P. M.; Laffoley, D. Key elements and steps in the process of developing ecosystem-based marine spatial planning. Marine Policy, 32:787-796, 2008. 


\section{Fis \\ COSTAS}

Gissi, E.; Menegon, S.; Sarretta, A.; Appiotti, F.; Maragno, D. et al. Addressing uncertainty in modelling cumulative impacts within maritime spatial planning in the Adriatic and Ionian region. PLOS ONE 12(7): e0180501, 2017. Disponível em: https://doi. org/10.1371/journal.pone.0180501.

Lana, $\quad$ P. C.; Marone, E.; Lopes, R. M.; Machado, E. C. The subtropical estuarine complex of Paranaguá Bay, Brazil. Ecological Studies, Coastal Marine Ecosystems of Latin America, n. 144, p. 131-145, 2001. Disponível em: https://link.springer.com/chapter/10.1007\%2F978-3-662-04482-7_11\#page-2.

Little, P. E. Ecologia política como etnografia: um guia teórico e metodológico. Horizontes Antropológicos, Porto Alegre, 12(25): 85-103, 2006. Disponível em: http://www.scielo.br/scielo.php?script=sci_arttext\&pid=S0104-71832006000100005.

Loureiro Fernandes, J. Contribuiçâo à geografia da praia de leste. Arq. Mus. Par., 6: 3-44, 1947.

Mcmanus, J. W.; Van Zwol, C.; Garces, L. R.; Sadacharan, D. A framework for future training in marine and coastal protected area management. 57. Malaysia: ICLARM Conference proceedings, 1998.

Miranda, J. I. Fundamentos de Sistemas de Informaçôes Geográficas. Brasília, 2010.

MMA. Atlas de Sensibilidade Ambiental ao Óleo da Bacia Marítima de Santos. Brasília, 2007.

MMA. Biodiversidade Brasileira: Avaliaçáo e identificação de áreas e açóes prioritárias para conservação, utilização sustentável e repartição dos benefícios da biodiversidade nos biomas brasileiros. Brasília, 2002.

MMA. Gestão Integrada da Zona Costeira do Paraná com ênfase na área marinha. Coletanea de mapas GERCO-PR. Curitiba, 2004. Disponível em: http://pdslitoral.com/gestao-integrada-da-zona-costeira-do-parana-com-enfase-na-area-marinha-pnma-ii/.

MPF - Ministério Público Federal. Disponível em: http://www.mpf.mp.br/atuacao-tematica/ccr4/dados-da-atuacao/grupos-de-trabalho/encerrados/ gt-pesca/portarias/ParquesAqucolas.pdf. Acesso em: 20/09/2018.

Noernberg, M. A.; Lautert, L. F. C.; Araújo, A. D.; Marone, E.; Angelotti, R.; Netto Jr., J. P. B.; Krug, L. A. Remote Sensing and GIS Integration for Modeling the Paranaguá Estuarine Complex -Brazil. Journal of Coastal Research, 39: 1627-1631, 2006.
Paula, E. V. Análise da produção de sedimentos na área de drenagem da Baía de Antonina, Paraná: Contribuiçóes ao Planejamento do Território. In: Reis, R. A.; Abrahão, C. M. S.; Tiepolo, L. M.; Chemin, M. Litoral do Paraná: Território e Perspectivas. Curitiba: Brazil Publishing, 2016. 11-35.

Pigosso, A. M. B.; Moscal, J. S.; Goldbach, J. Conflitos ambientais no litoral norte do Paraná: um mapeamento preliminar. Guaju, Matinhos, 4(1): 107-125, 2018. Disponível em: https://revistas.ufpr.br/guaju/ article/view/58660/35811.

Santos, P. A.; Quadros, J. Atores sociais e conflitos socioambientais: Uma caracterização da localidade do Parati, Guaratuba, Litoral do Paraná. In: Reis, R. A.; Abrahão, C. M. S.; Tiepolo, L. M.; Chemin, M. Litoral do Paraná: Território e Perspectivas. Curitiba: Brazil Publishing, 2016. 143-174.

Tomlin, C. D. A Map Algebra. In Proceedings of Harvard Computer Graphics Conference, at Cambridge, Mass, 1983.

Tuda, A. O.; Stevens, T. F.; Rodwell, L. D. Resolving coastal conflicts using marine spatial planning. Elsevier, v. 133, p. 59-68, 2014.

Unesco-IOC. Planificación Espacial Marina: una guia paso a paso hacia la Gestión Ecosistémica. 2009. Disponível em: http://mspes.ioc-unesco.org/guias/ pem-enfoque-paso-a-paso/.

Venegas-Li, R.; Levin, N.; Possingham, H.; Kark, S. 3D spatial conservation prioritisation: Accounting for depth in marine environments. Methods in Ecology and Evolution. DOI: 10.1111/2041-210x.12896.

Vigl, L. E.; Depellegrin, D.; Pereira, P.; Groot, R.; Tappeiner, E. Mapping the ecosystem service delivery chain: Capacity, flow, and demand pertaining to aesthetic experiences in mountain landscapes. Science of The Total Environment, 574: 422-436, 2017. 